\title{
EFFECT OF KEY DESIGN PARAMETERS ON BACTERIA COMMUNITY AND EFFLUENT POLLUTANT CONCENTRATIONS IN CONSTRUCTED WETLANDS USING MATHEMATICAL MODELS
}

David Sanchez-Ramos ${ }^{\text {a, }}$, Núria Agulló ${ }^{\text {b }}$, Roger Samsó c , Joan García ${ }^{\text {b }}$

${ }^{a}$ Research Group on Hydroecology, School of Civil Engineering, Universidad de Castilla-La Mancha, Av. Camilo José Cela s/n, E-13170 Ciudad Real, Spain (david.sanchezramos@uclm.es)

${ }^{\mathrm{b}}$ GEMMA - Group of Environmental Engineering and Microbiology, Department of Hydraulic, Maritime and Environmental Engineering, Universitat Politècnica de Catalunya-BarcelonaTech, c/ Jordi Girona, 1-3, Building D1, E-08034 Barcelona, Spain (joan.garcia@upc.edu)

${ }^{\mathrm{c}}$ IRSTEA, Freshwater Systems, Ecology and Pollution Research Unit, 5 rue de la Doua, CS70077, F69626, Villeurbanne cedex, France (roger.samso@irstea.fr)

* Corresponding author. Tel.: +34 926295 300; fax: +34 926295 391; E-mail address: david.sanchezramos@uclm.es

Keywords: Wastewater treatment; Depth; Aspect ratio; Modeling; CWM1; BIO_PORE.

ABSTRACT

Constructed wetlands are currently recognized as an effective environmental biotechnology for wastewater treatment, but their design is often carried out according to previous experience as the available knowledge is mostly empirical. The influence of design parameters on the contaminant removal efficiency of constructed wetlands is still under discussion. In this work, the effect of aspect ratio and water depth on the treatment efficiency of horizontal subsurface flow constructed wetlands (HSSF) under the Mediterranean climate was evaluated, using a mathematical model. For this purpose, experimental results from a pilot-scale HSSF system were modelled by simulating the dynamics of bacteria communities and effluent concentrations. Data from four wetlands of almost equal surface area but different aspect ratios and depth of the granular media were used. The HSSF system was fed with municipal wastewater previously treated in an Imhoff tank, originated in a municipality in Barcelona (Spain). The experimental results were simulated using the BIO_PORE model, developed in the COMSOL Multiphysics ${ }^{\mathrm{TM}}$ platform. Simulations with the BIO_PORE model fit well to the experimental results, showing a better removal efficiency for the shallower HSSF for COD (93.7\% removal efficiency) and ammonium and ammonia nitrogen (73.8\%). The aspect ratio showed a weak relationship with the bacteria distribution and the removal efficiency of the HSSF. In contrast, the water depth showed to be a determining factor: the depth of the HSSF conditioned its oxygenation and redox status, which affected the distribution and biomass of bacteria in the bed, and therefore the pollutant transformations within the wetland.

\section{Introduction}

Constructed wetlands (CWs) are a wastewater treatment technology used for the sanitation of small communities with thousands of facilities around the globe. However, the available knowledge about their functioning is currently limited, due to the complexity of the physical, chemical and biological processes occurring within them (Kumar and Zhao, 2011); consequently, the current state 
of knowledge on this environmental biotechnology is mainly case-specific and empirical (Samsó and García, 2014).

Design parameters (e.g. aspect ratio, water depth, hydraulic loading rate (HLR) and granular media size) have important effects on the treatment capacity of CWs. Thus, the design of CWs has been frequently performed by setting the design parameters according to previous experience in engineering practice, following a 'black box' approach (Kadlec and Wallace, 2009).

To bridge the knowledge gap between science and practice, several studies have evaluated the influence of one or more design parameters on the efficiency of CWs for the treatment of various types of pollutants under various environmental conditions (Kotti et al., 2010; Hijosa-Valsero et al., 2012; Stefanakis and Tsihrintzis, 2012). Particularly, the effect of water depth on the efficiency of horizontal subsurface flow constructed wetlands (HSSF) has been assessed less frequently than other parameters, being the available information currently limited to a few studies (García et al., 2005; Aguirre et al., 2005; Huang et al., 2005; Matamoros and Bayona, 2006).

The recent development of mathematical models simulating the complex functioning of CWs (e.g. Ojeda et al. (2008), Llorens et al. (2011b), Langergraber and Šimunek (2012), Mburu et al. (2012)) also provides a useful tool to improve the knowledge about their internal dynamics, making it possible to assess the influence of design parameters on the treatment efficiencies of CWs. Nevertheless, most existing models have been employed so far to match the simulated effluent concentrations and those measured experimentally, while the description of the internal functioning of the CWs has received less attention (Samsó and García, 2014). To overcome this situation and improve the understanding of the internal dynamics of subsurface flow CWs, Samsó and García (2013a) developed the BIO_PORE model using COMSOL Multiphysics ${ }^{\mathrm{TM}}$. This model implements the biokinetic expressions of Constructed Wetland Model number 1 (CWM1) (Langergraber et al., 2009) along with fluid flow and transport equations, which makes it able to describe the dynamics of the main bacterial groups and the fate and transport of the most common pollutants found in urban wastewaters in a mechanistic way.

One of the main strengths of BIO_PORE is its ability to simulate the progressive clogging of the granular media by inert solids and the consequent evolution in the location of bacterial communities, which are forced to move over time towards the outlet of the wetland. This observation gave place to what would be later called "the Cartridge Theory" (Samsó and García, 2014). The dynamic simulation of bacteria communities, whose location shifts over time depending on the availability of space and substrate, is the differentiating trait allowing BIO_PORE to produce realistic simulations of the internal functioning of subsurface flow CWs in the long-term. Furthermore, the application of numerical models such as BIO_PORE allow assessing the influence of design parameters on the internal dynamics and effluent pollutant concentrations of CWs, which would make this biotechnology more efficient and reliable (Samsó and García, 2014).

The objective of this work is to assess the effect of aspect ratio and water depth on the bacterial community and the treatment efficiency of HSSF under Mediterranean climate conditions using a mathematical model. For this purpose, experimental results from a pilot HSSF system were modelled with BIO_PORE model. Information on the effect of these design parameters on the functioning of HSSF based on a wide period of operation is currently limited (García et al., 2005) and hence we expect that the present study will contribute to give further insights on the influence of water depth and aspect ratio on the efficiency of HSSF.

\section{Material and Methods}

\subsection{Pilot system and experimental data}

The experimental data used in the simulations was collected from a pilot-scale HSSF system (Fig. 1) which treated part of the urban wastewater generated by a housing development in Les Franqueses del Vallès (Barcelona, Spain). The wastewater was initially screened and pre-treated in an Imhoff tank; then, the primary effluent was pumped to a distribution chamber from which it was equally 
distributed among four pairs of HSSF operating in parallel (A1, A2, B1, B2, C1, C2, D1, D2). All wetlands had the same surface area (54-55 $\mathrm{m}^{2}$ each), but each pair had a different aspect ratio (from 1:1 to 2.5:1). The two wetlands of each pair had different granular medium: one bed contained coarse granitic gravel (type 1) and the other small granitic gravel (type 2). In all the wetlands, the first $0.30 \mathrm{~m}$ of the beds length contained very coarse granitic gravel, as this area operated as a mixing zone, which received the influent wastewater. The average water depth of the wetlands was $0.50 \mathrm{~m}$, except for the pair with longest aspect ratio (type D), which were shallower $(0.27 \mathrm{~m})$. All the wetlands were planted with common reed (Phragmites australis) and had a bottom slope of $1 \%$. A detailed description of the pilot-scale HSSF system can be found in Aguirre et al. (2005), García et al. (2004a,b, 2007) and Huang et al. (2005).

Fig. 1. Schematic diagram of the pilot-scale horizontal subsurface flow constructed wetland system. Type 1 beds contained coarse granitic gravel while type 2 beds contained small granitic gravel. The rest of characteristics of the wetlands are summarized in Table 1. Reprinted from García et al. (2004a).

In the present study only data from the four HSSF with small granitic gravel (type 2: $D_{60}=3.5$ $\mathrm{mm}$, uniformity coefficient $C_{\mathrm{u}}=1.7,40 \%$ initial porosity) were analyzed (Table 1 ), as the model used for simulations was calibrated for this granular medium (Samsó and García, 2013a).

Table 1. Summary of the characteristics of the four horizontal subsurface flow constructed wetlands (A, B, C and D). These wetlands were named A2, B2, C2 and D2 in García et al. (2004a,b).

\begin{tabular}{lcccc}
\hline & A & B & C & D \\
\hline Length $(\mathrm{m})$ & 7.4 & 9.0 & 10.3 & 11.7 \\
Width $(\mathrm{m})$ & 7.4 & 6.0 & 5.3 & 4.7 \\
Aspect ratio & $1: 1$ & $1.5: 1$ & $2: 1$ & $2.5: 1$ \\
Surface area $\left(\mathrm{m}^{2}\right)$ & 54.8 & 54.0 & 54.6 & 55.0 \\
Water depth $(\mathrm{m})$ & 0.5 & 0.5 & 0.5 & 0.27 \\
\hline
\end{tabular}

The treatment system went into operation in March 2001, with variable flow rates corresponding with HLRs between 20 and $45 \mathrm{~mm} \mathrm{~d}^{-1}$. Sampling campaigns were carried out from May 2001 to December 2003 with a frequency of three to four times per month (García et al., 2005). Besides in situ measurements of $\mathrm{pH}$ and temperature, influent and effluent samples were collected and analyzed for $\mathrm{COD}, \mathrm{BOD}_{5}$, ammonia and dissolved reactive phosphorus; other components used in the simulations 
1 (i.e. sulfate sulfur, nitrate and nitrite nitrogen) were monitored less frequently and have been obtained

2 from García et al. (2005).

\subsection{Model description}

Simulations were run using the BIO_PORE model (Samsó and García, 2013a), a mathematical code developed in the COMSOL Multiphysics ${ }^{\mathrm{TM}}$ finite elements platform for the simulation of the internal functioning of subsurface flow CWs. This numerical model implements fluid flow and transport equations in a $2 \mathrm{D}$ domain that represents the wet area in the longitudinal section of a wetland. BIO_PORE model incorporates the biokinetic reactions described in the CWM1 (Langergraber et al., 2009), a widely accepted formulation for the simulation of the main biochemical transformation and degradation processes in subsurface flow CWs. CWM1 is mostly based on the Activated Sludge Model 1 (ASM1) (Henze et al., 2000) and on the Anaerobic Digestion Model 1 (ADM1) (Batstone et al., 2002) formulations, and therefore it incorporates aerobic, anoxic and anaerobic processes. This biokinetic model describes the growth and decay of 6 functional bacterial groups that are considered the most relevant on CWs (Table 2), as well as the fate and transport of 10 substrates: dissolved oxygen, particulate and dissolved fractions of COD, nitrate and nitrite nitrogen, ammonium and ammonia nitrogen, sulfate sulfur and dihydrogen sulfide sulfur.

Table 2. Functional bacterial groups and components considered in BIO_PORE model, adapted from CWM1 (Langergraber et al., 2009).

\begin{tabular}{llll}
\hline Component & Description & Phase \\
\cline { 1 - 3 } \cline { 3 - 3 } XH & Heterotrophic bacteria & Particulate \\
$\mathrm{XA}$ & Autotrophic nitrifying bacteria & Particulate \\
$\mathrm{XFB}$ & Fermenting bacteria & Particulate \\
$\mathrm{XAMB}$ & Acetotrophic methanogenic bacteria & Particulate \\
$\mathrm{XASRB}$ & Acetotrophic sulfate reducing bacteria & Particulate \\
$\mathrm{XSOB}$ & Sulfide oxidizing bacteria & Particulate \\
$\mathrm{SO}$ & Dissolved oxygen & Aqueous \\
$\mathrm{SF}$ & Soluble fermentable COD & Aqueous \\
$\mathrm{SA}$ & Fermentation products as acetate as COD & Aqueous \\
$\mathrm{SI}$ & Inert soluble COD & Aqueous \\
$\mathrm{XS}$ & Slowly biodegradable particulate COD & Particulate / Aqueous \\
$\mathrm{XI}$ & Inert particulate COD & Particulate / Aqueous \\
$\mathrm{SNO}$ & Nitrite and nitrate N & Aqueous \\
$\mathrm{SNH}$ & Ammonium and ammonia N & Aqueous \\
$\mathrm{SSO}_{4}$ & Sulfate sulfur & Aqueous \\
$\mathrm{SH}_{2} \mathrm{~S}$ & Dihydrogen sulfide sulfur & Aqueous \\
\hline
\end{tabular}

(Knowles et al., 2011; Samsó et al., 2016). BIO_PORE includes two main modifications with respect to the original formulation of CWM1 (Meyer et al., 2015): i) two logistic functions are added in the growth expressions of all bacterial groups to avoid the unrealistic exponential growth of bacteria biomass, which affects most of the models for CWs based on the ASM1 formulation; and ii) slowly biodegradable and inert particulate COD are divided into aqueous and solid phases, to enable the simulation of the retention and re-suspension of the solid phase. Thereby, the consideration of attachment and detachment processes allows simulating the accumulation of particulate matter in the granular media and its effect on bacterial growth.

The BIO_PORE model was previously calibrated using experimental data obtained in the same pilot-scale system described in this work (Samsó and García, 2013a). 


\subsection{Simulation strategy}

Long-term simulations (500 days) were carried out to reach bacteria stability in the wetlands. The same input data were used for the 4 different configurations of HSSF, which allows interpreting the effect of design parameters (namely aspect ratio and water depth) on bacteria communities and effluent pollutant concentrations. Constant input values for HLR $\left(14 \mathrm{~mm} \mathrm{~d}^{-1}\right)$, water temperature (20 ${ }^{\circ} \mathrm{C}$ ) and influent concentrations (Table 3) were used to enable the interpretation and comparison of the results. The values considered in the simulations for the influent pollutant concentrations were obtained from the data average of the 32-months monitoring in the pilot-scale HSSF system (García et al., 2005). The influent COD was fractionated according with the recommended values for primary effluents specified in ASM1 (Henze et al., 2000).

Table 3. Influent concentrations used for simulations for the different components considered in CWM1, based on the experimental data from the pilot-scale horizontal subsurface flow constructed wetland system.

\begin{tabular}{ccc}
\hline Component & Value & Units \\
\hline $\mathrm{SO}$ & 0 & $\mathrm{mgO}_{2} \mathrm{~L}^{-1}$ \\
$\mathrm{SF}$ & 41 & $\mathrm{mgO}_{2} \mathrm{~L}^{-1}$ \\
$\mathrm{SA}$ & 55 & $\mathrm{mgO}_{2} \mathrm{~L}^{-1}$ \\
$\mathrm{SI}$ & 14 & $\mathrm{mgO}_{2} \mathrm{~L}^{-1}$ \\
$\mathrm{XS}$ & 138 & $\mathrm{mgO}_{2} \mathrm{~L}^{-1}$ \\
$\mathrm{XI}$ & 28 & $\mathrm{mgO}_{2} \mathrm{~L}^{-1}$ \\
$\mathrm{SNH}$ & 57 & $\mathrm{mgN} \mathrm{L}^{-1}$ \\
$\mathrm{SNO}$ & 0 & $\mathrm{mgN} \mathrm{L}^{-1}$ \\
$\mathrm{SSO}_{4}$ & 72 & $\mathrm{mgS} \mathrm{L}^{-1}$ \\
$\mathrm{SH}_{2} \mathrm{~S}$ & 0 & $\mathrm{mgS} \mathrm{L}^{-1}$ \\
\hline
\end{tabular}

The input of bacteria biomass with the influent wastewater was obviated, as it is considered negligible compared with the biomass growing in the CWs (Truu et al., 2009). Otherwise, the initial concentrations in the wetlands for bacteria communities and for the particulate and dissolved components considered in CWM1 were set to $0.001 \mathrm{mg} \mathrm{L}^{-1}$ as in Samsó and García (2013a,b), in order to simulate start-up conditions. Oxygen release and nitrogen uptake by plant roots (applied to the top $30 \mathrm{~cm}$ of the granular medium), as well as passive diffusion of atmospheric oxygen into the water, were also considered in the simulations as in Samsó and García (2013a,b).

\section{Results and Discussion}

\subsection{Bacteria distribution}

The bacteria distribution obtained in the simulations with the BIO_PORE model for the 4 configurations of HSSF was very similar to the observed in previous studies (Llorens et al., 2011b; Samsó and García, 2013a,b). The bacteria communities were well-developed and stabilized after the 500-days simulations, which is a critical factor for an efficient water treatment in subsurface flow CWs (Torsvik and Ovreas, 2002; Wohl et al., 2004). The ability of BIO_PORE model to simulate the progressive clogging of the granular media and the temporal dynamics of bacterial groups allows performing long-term simulations in which bacteria community stabilization is reached. In fact, experimental studies in subsurface flow CWs mesocosms estimated that the stabilization of bacteria communities takes between 75 and 100 days (Ramond et al., 2012; Truu et al., 2009; Weber and 
Legge, 2011). However, Samsó and García (2013b) suggested that bacteria communities stabilization is a slower process (100-250 days), based on simulations with BIO_PORE model in the same pilotscale HSSF system than this work. In any case, the performed 500-days simulations had been long enough for the stabilization of the bacteria communities. On the other hand, bacteria communities distribution in CWs is still mainly based on assumption and circumstantial evidence (Krasnits et al., 2009; Mburu et al., 2012; Ojeda et al., 2008), since there are only a few studies on the subject. Therefore, the distribution of bacteria communities obtained in the simulations cannot be directly calibrated and must be considered only as an output of the model, as in Samsó and García (2013a,b).

After the stabilization of the bacterial community, the simulations showed an evident separation between the aerobic bacteria (functional groups $\mathrm{XH}, \mathrm{XA}$ and $\mathrm{XSOB}$ ) and the anaerobic bacteria (functional groups XFB, XAMB and XASRB) (Figs. 2 and 3). The aerobic bacteria groups were distributed mainly near the surface in a few centimeters at the top of the wetlands, benefiting from the oxygen released by plant roots and the passive diffusion of atmospheric oxygen into the water. Heterotrophic bacteria $(\mathrm{XH})$ was the aerobic bacteria group located the closest to the inlet (Fig. 2a), reaching high concentrations just behind fermenting bacteria (XFB), which grew throughout all the depth of the beds right close to the inlet (Fig. 2d). Nitrifying bacteria (XA) were located further towards the outlet than XH (Fig. 2b), benefiting from the absence of enough COD to sustain XH growth and the resulting availability of dissolved oxygen. Sulfide oxidizing bacteria (XSOB) were distributed mostly after XA (Fig. 2c) because of the low concentration of dihydrogen-sulfide sulfur in the aerobic layer, so they took advantage of the nitrate produced by XA to grow mainly in anoxic conditions.

The anaerobic bacteria groups were more widespread than the aerobic groups, indicating the predominance of anaerobic conditions in the wetlands. Sulfate reducing bacteria (XASRB) were located behind fermenting bacteria XFB (Fig. 2e) with both longitudinal and vertical gradients: their bacteria biomass concentrations decreased from inlet to outlet and from the bottom to the surface of the beds. Regarding methanogenic bacteria (XAMB) (Fig. 2f), they reached high concentrations behind fermenting bacteria (XFB) as XAMB benefit from the fermentation products as acetate (a byproduct of XFB activity). Thus, the settling of a high biomass concentration of XFB in almost the entire depth of the wetlands enabled the growth of XAMB at almost all depths of the beds.
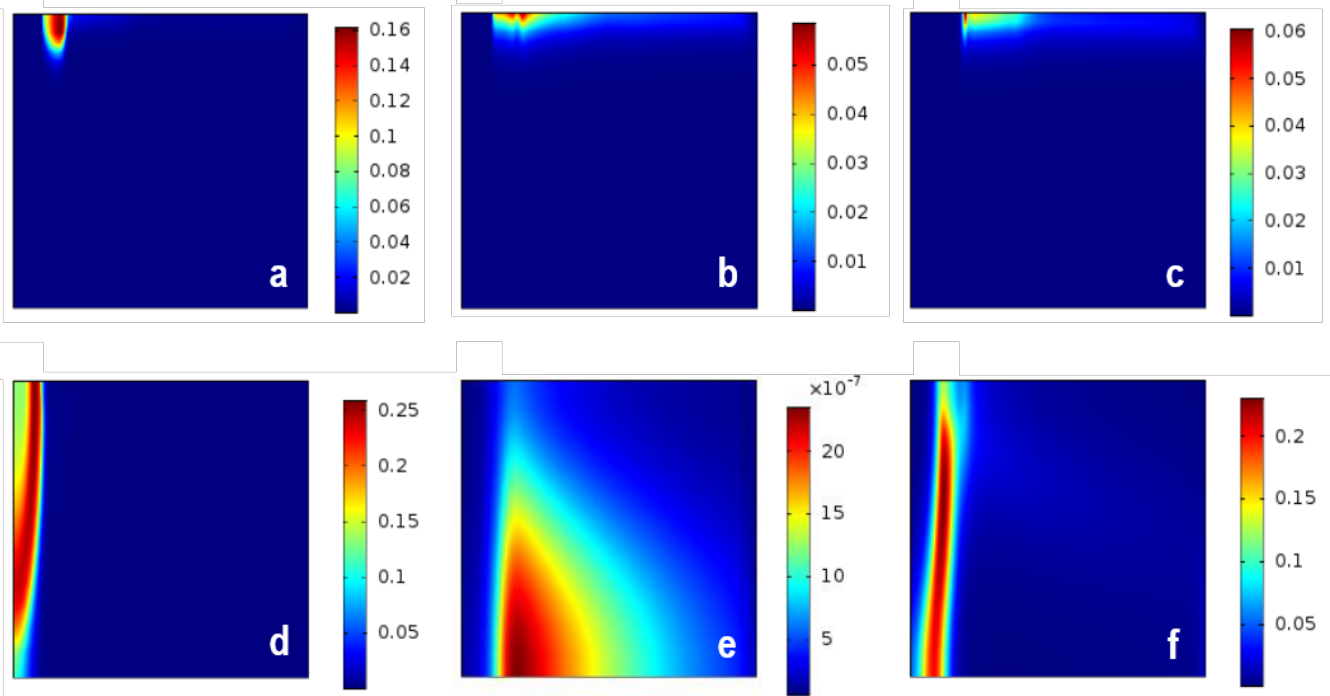

30

31

32

33

34

35

36

37

Fig. 2. Distribution of a) heterotrophic (XH), b) nitrifying (XA), c) sulfide oxidizing (XSOB), d) fermenting (XFB), e) sulfate reducing (XASRB) and f) methanogenic (XAMB) bacteria in the horizontal subsurface flow constructed wetland of type $C$ after 500 days of simulation (results for HSSF type A and B are not shown as they were quite similar to this results). The keys at the right of the figures indicate bacteria concentration in mgCOD L ${ }^{-1}$. The images are longitudinal cross sections of the wetland, deformed to fit a reasonable size. The $x^{-}$ axis of each image represents the longitudinal direction of the wetland and the $y$-axis the depth of the wetland (from 0 to $0.5 \mathrm{~m}$ ). 

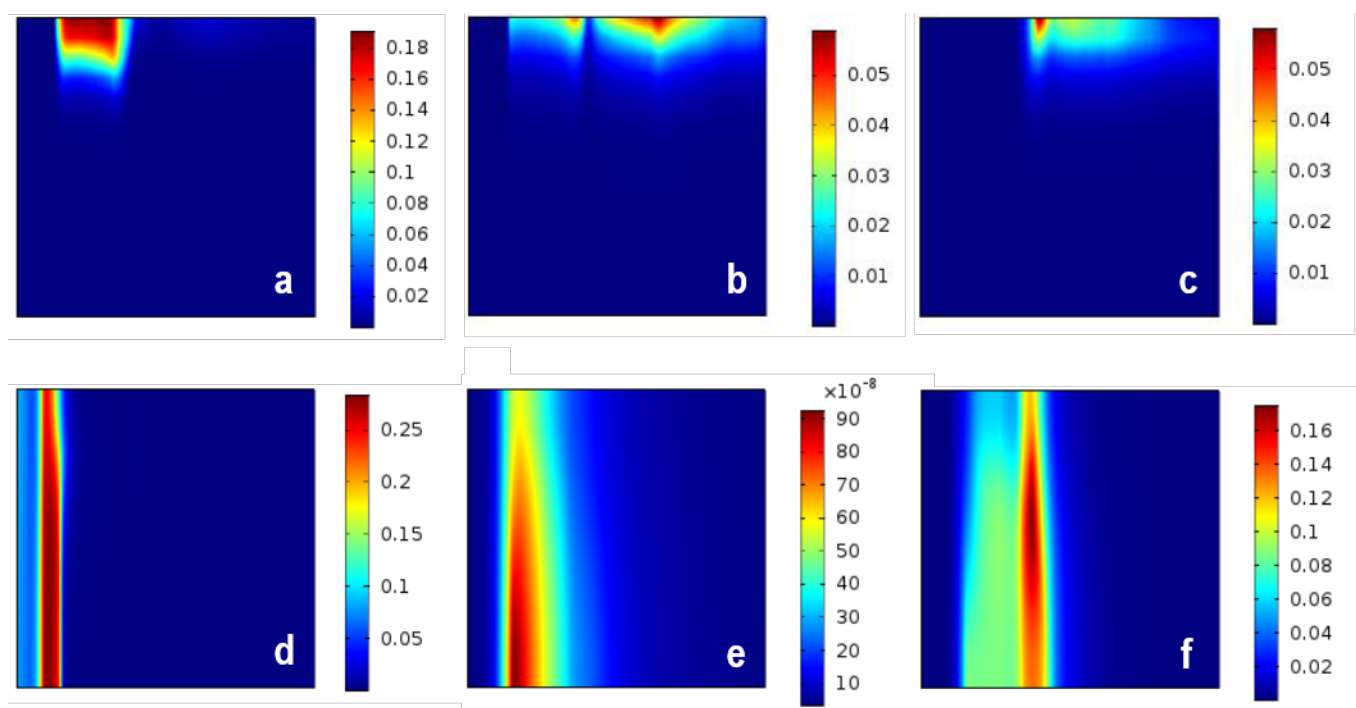

Fig. 3. Distribution of a) heterotrophic (XH), b) nitrifying (XA), c) sulfide oxidizing (XSOB), d) fermenting (XFB), e) sulfate reducing (XASRB) and f) methanogenic (XAMB) bacteria in the horizontal subsurface flow constructed wetland type $\mathrm{D}$ after 500 days of simulation. The keys at the right of the figures indicate bacteria concentration in mgCOD L ${ }^{-1}$. The images are longitudinal cross sections of the wetland, deformed to fit a reasonable size. The $\mathrm{x}$-axis of each image represents the longitudinal direction of the wetland and the $\mathrm{y}$-axis the depth of the wetland (from 0 to $0.27 \mathrm{~m}$ ).

No clear differences were found in bacteria distribution obtained in the simulations for HSSF types $\mathrm{A}, \mathrm{B}$ and $\mathrm{C}$, showing little influence of the aspect ratio. Contrastingly, the depth of the wetland was a key factor, as the bacteria distribution obtained for HSSF type D was quite different from those of type A, B and C. This shallower HSSF (D) was more oxygenated, because a larger fraction of its pore volume received the oxygen released by plant roots and by passive diffusion of atmospheric oxygen. This fact caused the existence of more sites with positive (or less negative) redox conditions in the wetland, resulting in larger populations of aerobic bacteria: heterotrophic (Fig. 3a), autotrophic nitrifying (Fig. 3b) and sulfide oxidizing bacteria (Fig. 3c). In contrast, acetotrophic methanogenic bacteria (Fig. 3e) and acetotrophic sulfate reducing bacteria (Fig. 3f) were less preponderant and were displaced towards the outlet of the wetland.

The biomass concentration of fermenting bacteria (XFB) was quite similar for all the HSSF (Figs. $2 \mathrm{~d}$ and $3 \mathrm{~d}$ ), but in the HSSF type D its distribution was slightly displaced towards the outlet of the wetland, creating an area without bacteria biomass in the inlet section. The accumulation of not biodegradable inert solids (which enter the wetland in the influent wastewater or are produced by the death and decomposition of bacteria cells) ) causes the filling of the porosity close to the inlet, thus avoiding further bacteria development, as observed in Samsó and García (2013b). The clogged area progresses towards the outlet with time, causing the displacement and reduction of the active bacteria zone (Samsó and García, 2014). This effect is much more remarkable in the HSSF type D because of its lower pore volume available for the accumulation of solids (shallower beds), producing a faster clogging of the wetland.

For all the simulations, bacteria biomass was present in the whole wetland, but the active bacteria zone (with high concentration) was rather small: aerobic bacteria communities were distributed in a narrow horizontal strip close to the surface, while anaerobic bacteria communities were distributed in a vertical strip close to the inlet. This distribution pattern is characteristic in HSSF, as they behave as non-ideal plug-flow reactors with both substrates and bacterial concentrations showing longitudinal gradients in their concentrations (decreasing from inlet to outlet) (García et al., 2010; Vacca et al., 2005). 


\subsection{Removal efficiencies}

As it happened with bacteria distribution, no significant differences were found in the removal efficiencies obtained for HSSF types A, B and C, showing little influence of the aspect ratio. Instead, the depth of the wetland showed again a key importance, as the removal efficiencies obtained for HSSF type D were quite different from those of type A, B and C (Fig. 4).

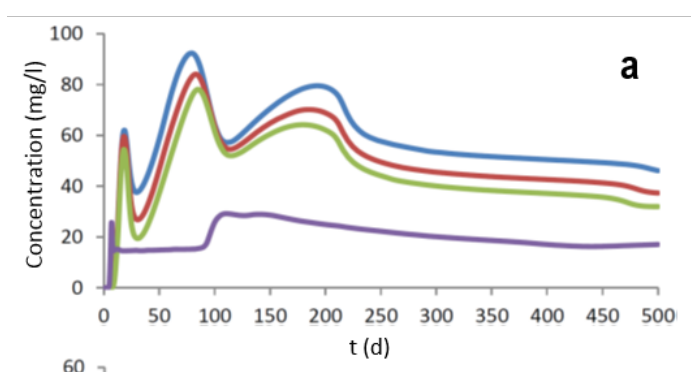

a
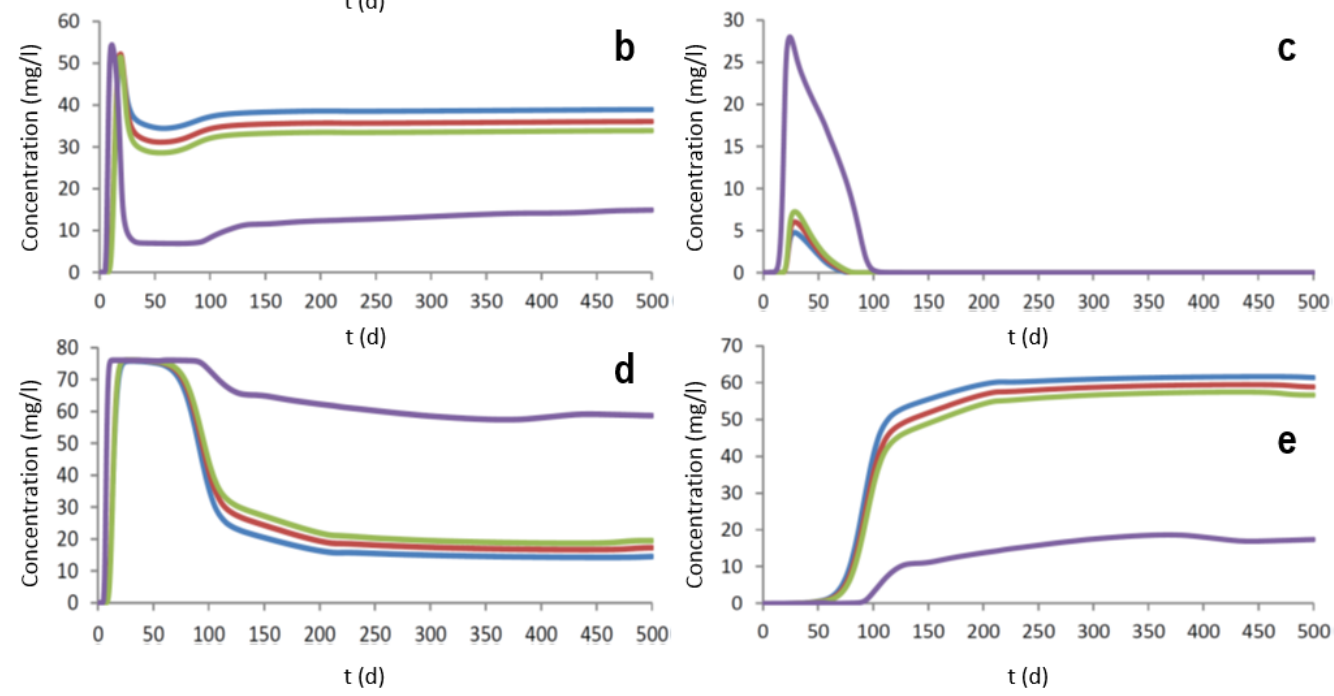

Fig. 4. Changes in effluent concentrations of a) total COD (mgCOD L $\left.{ }^{-1}\right)$, b) ammonium and ammonia nitrogen $(\mathrm{SNH})\left(\mathrm{mgN} \mathrm{L}^{-1}\right)$, c) nitrite and nitrate nitrogen (SNO) $\left(\mathrm{mgN} \mathrm{L}^{-1}\right)$, d) sulfate sulfur $\left(\mathrm{SSO}_{4}\right)\left(\mathrm{mgS} \mathrm{L}^{-1}\right)$ and e) dihydrogen-sulfide sulfur $\left(\mathrm{SH}_{2} \mathrm{~S}\right)\left(\mathrm{mgS} \mathrm{L}^{-1}\right)$, for the horizontal subsurface constructed wetlands types A, B, C and D.

Regarding the stabilization of the COD concentration in the effluent, it occurred approximately at 240 days of simulation for HSSF A, B and C, without relying on the aspect ratio (Fig. 4a). The most visible difference was between the HSSF type D and the others, as the shallow HSSF reached the stabilization of the COD concentration in the effluent at around 100 days of simulation. For the rest of the components in the model, the stabilization in the effluent was reached earlier and with fewer differences between the different HSSF: 75-125 days for nitrogen components (Fig. 4b and 4c) and about 200 days for sulfur components (Fig. 4d and 4e).

Comparing the results of the simulations with those obtained during the experimental study, the general trend was similar in both cases (Table 4), although there were differences in magnitude mainly because of the differences in the hydraulic and organic loading, which were simulated with constant values in the model. The experimental results showed that the shallower HSSF (type D) had higher COD, $\mathrm{BOD}_{5}$ and ammonia removal efficiency over the 3 years (García et al., 2005). The simulations with the BIO_PORE model confirmed these results, showing a better removal efficiency for HSSF type D for COD and ammonium and ammonia nitrogen. Nitrite and nitrate nitrogen were not detected in the effluent of the 4 HSSF in the simulations (Fig. 4c). On the other hand, the removal efficiency for sulfate sulfur $\left(\mathrm{SO}_{4}-\mathrm{S}\right)$ was the lowest $(18.4 \%)$ for HSSF type D. However, this shallower HSSF achieved the lower concentration for dihydrogen-sulfide sulfur $\left(\mathrm{H}_{2} \mathrm{~S}\right)$, since sulfate and dihydrogen-sulfide sulfur are complementary in the formulation of the CWM1. Thus, the higher 
redox potential in the shallower HSSF attenuated the metabolism of the anaerobic sulfate reducing bacteria and stimulated the metabolism of the aerobic sulfide oxidizing bacteria. Besides, it is important to remark that dihydrogen-sulfide sulfur can be toxic for most bacteria groups (Samsó and García, 2013b; Wu et al., 2013), so high concentrations of this compound can reduce the removal efficiency of HSSF.

Table 4. Removal efficiencies of COD, $\mathrm{NH}_{4}-\mathrm{N}$ and $\mathrm{SO}_{4}-\mathrm{S}$ for HSSF type A, B, C and D in the simulations with BIO_PORE model (end of 500-days simulation) and in the experimental study (average values corresponding to different operation conditions than the simulations) (García et al., 2005).

\begin{tabular}{|c|c|c|c|c|c|}
\hline \multirow[b]{2}{*}{ HSSF } & \multicolumn{2}{|c|}{$\begin{array}{c}\text { COD } \\
\text { removal efficiency (\%) }\end{array}$} & \multicolumn{2}{|c|}{$\begin{array}{c}\mathrm{NH}_{4}-\mathrm{N} \\
\text { removal efficiency (\%) }\end{array}$} & \multirow{2}{*}{$\begin{array}{c}\mathrm{SO}_{4}-\mathrm{S} \\
\text { removal efficiency (\%) } \\
\text { BIO_PORE }\end{array}$} \\
\hline & BIO_PORE & Experimental data & BIO_PORE & Experimental data & \\
\hline$A$ & 83 & 63 & 32 & 26 & 80 \\
\hline B & 86 & 65 & 37 & 28 & 76 \\
\hline C & 88 & 65 & 40 & 30 & 73 \\
\hline D & 94 & 79 & 74 & 51 & 18 \\
\hline
\end{tabular}

Regarding the results for COD, the shallower HSSF (which had a higher redox potential because of the greater oxygenation) obtained a better removal efficiency as the aerobic degradation of COD is more efficient than anaerobic (Tiner, 2009). For this reason, the depth of HSSF can be considered a determining factor in the removal efficiency of COD. Reducing the water depth of HSSF has also showed positive effects on their pollutant removal efficiencies in previous studies, because of a better hydraulic efficiency (Holland et al., 2004) or due to its lower negative redox potential (Matamoros and Bayona, 2006).

\section{Conclusions}

The BIO_PORE model allowed to contrast and give insight into the experimental results of 4 HSSF with different configurations in term of aspect ratio and water depth. While the water depth showed to be a determining factor in the removal efficiency of the wetlands, the aspect ratio showed a weak relationship with the removal efficiency. The depth of the HSSF conditioned the redox status of the wetlands because of the different oxygenation: shallow beds resulted in a greater contact of the water with the root of the macrophytes (larger oxygen release by plant roots) and with the atmosphere (larger passive diffusion of atmospheric oxygen). Thus, the water depth influenced the distribution and biomass of bacteria in the bed, which in turn conditioned the pollutant transformations within the wetland and their concentrations in the effluent.

As aerobic degradation of organic matter is more efficient than anaerobic, and a higher redox potential of the wetland also enhances nitrification, the removal efficiency for COD and ammonium and ammonia nitrogen resulted higher for shallow HSSF. Besides, shallow HSSF reach before the stabilization of the COD concentration in the effluent. Otherwise, shallow HSSF have a bigger risk of becoming ineffective in a shorter time due to the accumulation of inert solids, which causes the displacement and reduction of the active bacteria zone. Therefore, the risk of clogging, which is considered one of the biggest operational problems for CWs, can be seen as the main drawback related with shallow wetlands.

Understanding such effects of the water depth of HSSF on their functioning and removal efficiency will aid in the design and management of this biotechnology. 


\section{Acknowledgements}

This work was possible thanks to the funding from the Spanish Ministry of Innovation and Science for the NEWWET2008 Project (CTM2008-06676-C05-01) and from the NAWATECH FP7 Project (308336). David Sanchez-Ramos also acknowledges the scholarship provided by the Universidad de Castilla-La Mancha for the research stay in the GEMMA Research Group. Authors would also like to thank Joan Grau and Ricardo Torres from the Fluid Mechanics Department of UPC, for sharing the computer cluster where the simulations were run.

\section{References}

Aguirre, P., Ojeda, E., García, J., Barragán, J., Mujeriego, R., 2005. Effect of water depth on the removal of organic matter in horizontal subsurface flow constructed wetlands. J. Environ. Sci. Health - Part ToxicHazardous Subst. Environ. Eng. 40, 1457-1466. doi:10.1081/ESE200055886

Batstone, D.J., Keller, J., Angelidaki, I., Kalyuzhnyi, S.V., Pavlostathis, S.G., Rozzi, A., Sanders, W.T., Siegrist, H., Vavilin, V.A., 2002. The IWA Anaerobic Digestion Model No 1 (ADM1). Water Sci. Technol. 45, 65-73.

\section{Coleman, J., Hench, K., Garbutt, K., Sexstone, A., Bissonnette, G., Skousen, J., 2001. Treatment o domestic wastewater by three plant species in constructed wetlands. Water. Air. Soil Pollut 128, 283-295. doi:10.1023/A:1010336703606}

García, J., Aguirre, P., Barragán, J., Mujeriego, R., Matamoros, V., Bayona, J.M., 2005. Effect of key design parameters on the efficiency of horizontal subsurface flow constructed wetlands. Ecol. Eng. 25, 405-418. doi:10.1016/j.ecoleng.2005.06.010

García, J., Aguirre, P., Mujeriego, R., Huang, Y., Ortiz, L., Bayona, J.M., 2004a. Initial contaminant removal performance factors in horizontal flow reed beds used for treating urban wastewater. Water Res. 38, 1669-1678. doi:10.1016/j.watres.2004.01.011

García, J., Capel, V., Castro, A., Ruíz, I., Soto, M., 2007. Anaerobic biodegradation tests and gas emissions from subsurface flow constructed wetlands. Bioresour. Technol. 98, 3044-3052. doi:10.1016/j.biortech.2006.10.016

García, J., Chiva, J., Aguirre, P., Álvarez, E., Sierra, J.P., Mujeriego, R., 2004b. Hydraulic behaviour of horizontal subsurface flow constructed wetlands with different aspect ratio and granular medium size. Ecol. Eng. 23, 177-187. doi:10.1016/j.ecoleng.2004.09.002

García, J., Rousseau, D.P.L., Morató, J., Lesage, E., Matamoros, V., Bayona, J.M., 2010. Contaminant removal processes in subsurface-flow constructed wetlands: A review. Crit. Rev. Environ. Sci. Technol. 40, 561-661. doi:10.1080/10643380802471076

Henze, M., Gujer, W., Mino, T., van Loosdrecht, M.C.M., 2000. Activated sludge models ASM1, ASM2, ASM2d and ASM3. IWA Publishing.

Hijosa-Valsero, M., Sidrach-Cardona, R., Bécares, E., 2012. Comparison of interannual removal variation of various constructed wetland types. Sci. Total Environ. 430, 174-183. doi:10.1016/j.scitotenv.2012.04.072

Holland, J.F., Martin, J.F., Granata, T., Bouchard, V., Quigley, M., Brown, L., 2004. Effects of wetland depth and flow rate on residence time distribution characteristics. Ecol. Eng. 23, 189203. doi:10.1016/j.ecoleng.2004.09.003

Huang, Y., Ortiz, L., Aguirre, P., García, J., Mujeriego, R., Bayona, J.M., 2005. Effect of design parameters in horizontal flow constructed wetland on the behaviour of volatile fatty acids and volatile alkylsulfides. Chemosphere 59, 769-777. doi:10.1016/j.chemosphere.2004.11.015

Kadlec, R.H., Wallace, S., 2009. Treatment Wetlands, Second Edition. CRC Press. 


\section{Knowles, P., Dotro, G., Nivala, J., García, J., 2011. Clogging in subsurface-flow treatment wetlands Occurrence and contributing factors. Ecol. Eng. 37, 99-112.
doi:10.1016/j.ecoleng.2010.08.005}

Kotti, I.P., Gikas, G.D., Tsihrintzis, V.A., 2010. Effect of operational and design parameters on removal efficiency of pilot-scale FWS constructed wetlands and comparison with HSF systems. Ecol. Eng. 36, 862-875. doi:10.1016/j.ecoleng.2010.03.002

Krasnits, E., Friedler, E., Sabbah, I., Beliavski, M., Tarre, S., Green, M., 2009. Spatial distribution of major microbial groups in a well established constructed wetland treating municipal wastewater. Ecol. Eng. 35, 1085-1089. doi:10.1016/j.ecoleng.2009.03.020

Kumar, J.L.G., Zhao, Y.Q., 2011. A review on numerous modeling approaches for effective, economical and ecological treatment wetlands. J. Environ. Manage. 92, 400-406. doi:10.1016/j.jenvman.2010.11.012

Langergraber, G., Rousseau, D.P.L., García, J., Mena, J., 2009. CWM1: A general model to describe biokinetic processes in subsurface flow constructed wetlands. Water Sci. Technol. 59, 16871697. doi:10.2166/wst.2009.131

Langergraber, G., Šimůnek, J., 2012. Reactive transport modeling of subsurface flow constructed wetlands using the HYDRUS wetland module. Vadose Zone J. 11. doi:10.2136/vzj2011.0104

\section{Llorens, E., Saaltink, M.W., García, J., 2011a. CWM1 implementation in RetrasoCodeBright: Firs results using horizontal subsurface flow constructed wetland data. Chem. Eng. J. 166, 224 232. doi:10.1016/j.cej.2010.10.065}

Llorens, E., Saaltink, M.W., Poch, M., García, J., 2011b. Bacterial transformation and biodegradation processes simulation in horizontal subsurface flow constructed wetlands using CWM1RETRASO. Bioresour. Technol. 102, 928-936. doi:10.1016/j.biortech.2010.09.038

Matamoros, V., Bayona, J.M., 2006. Elimination of pharmaceuticals and personal care products in subsurface flow constructed wetlands. Environ. Sci. Technol. 40, 5811-5816. doi:10.1021/es0607741

Mburu, N., Sanchez-Ramos, D., Rousseau, D.P.L., van, B., Thumbi, G., Stein, O.R., Hook, P.B., Lens, P.N.L., 2012. Simulation of carbon, nitrogen and sulphur conversion in batch-operated experimental wetland mesocosms. Ecol. Eng. 42, 304-315. doi:10.1016/j.ecoleng.2012.02.003

Meyer, D., Chazarenc, F., Claveau-Mallet, D., Dittmer, U., Forquet, N., Molle, P., Morvannou, A., Pálfy, T., Petitjean, A., Rizzo, A., Samsó, C., Scholz, M., Soric, A., Langergraber, G., 2015. Modelling constructed wetlands: Scopes and aims - a comparative review. Ecol. Eng. 80, 205-213. doi:10.1016/j.ecoleng.2014.10.031

Ojeda, E., Caldentey, J., Saaltink, M.W., García, J., 2008. Evaluation of relative importance of different microbial reactions on organic matter removal in horizontal subsurface-flow constructed wetlands using a 2D simulation model. Ecol. Eng. 34, 65-75. doi:10.1016/j.ecoleng.2008.05.007

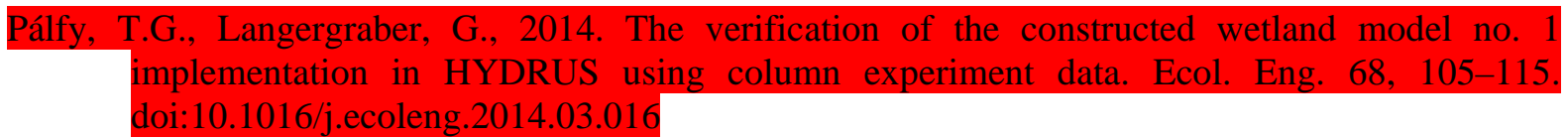

Ramond, J.-B., Welz, P.J., Cowan, D.A., Burton, S.G., 2012. Microbial community structure stability, a key parameter in monitoring the development of constructed wetland mesocosms during start-up. Res. Microbiol. 163, 28-35. doi:10.1016/j.resmic.2011.09.003

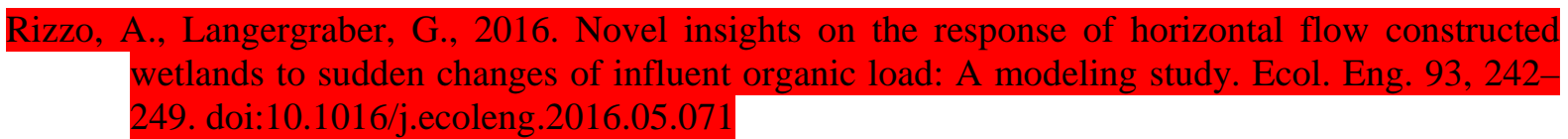




\section{Samsó,} and accumulated inert solids on the effluent pollutant concentrations predicted by the
constructed wetlands model BIO_PORE. Ecol. Eng. 80, 172-180.
doi:10.1016/j.ecoleng.2014.09.069

Samsó, R., García, J., 2014. The cartridge theory: A description of the functioning of horizontal subsurface flow constructed wetlands for wastewater treatment, based on modelling results. Sci. Total Environ. 473-474, 651-658. doi:10.1016/j.scitotenv.2013.12.070

Samsó, R., García, J., 2013. Bacteria distribution and dynamics in constructed wetlands based on modelling results. Sci. Total Environ. 461-462, 430-440. doi:10.1016/j.scitotenv.2013.04.073

Samsó, R., García, J., 2013. BIO_PORE, a mathematical model to simulate biofilm growth and water quality improvement in porous media: Application and calibration for constructed wetlands. Ecol. Eng. 54, 116-127. doi:10.1016/j.ecoleng.2013.01.021

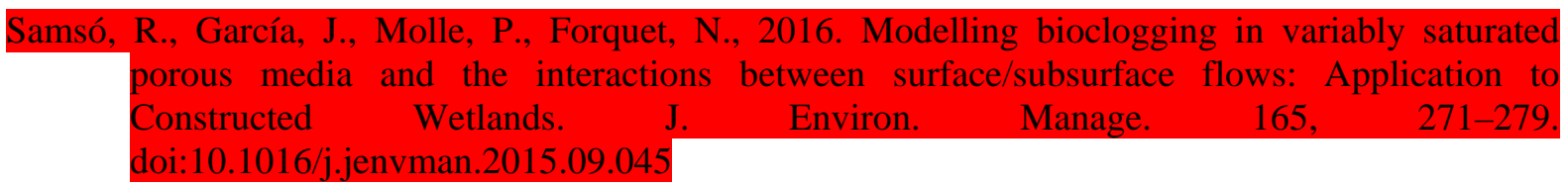

Stefanakis, A.I., Tsihrintzis, V.A., 2012. Effect of various design and operation parameters on performance of pilot-scale Sludge Drying Reed Beds. Ecol. Eng. 38, 65-78. doi:10.1016/j.ecoleng.2011.10.003

Tiner, R.W., 2009. Wetland Hydrology A2 - Likens, Gene E., in: Encyclopedia of Inland Waters. Academic Press, Oxford, pp. 778-789.

Torsvik, V., Øvreås, L., 2002. Microbial diversity and function in soil: from genes to ecosystems. Curr. Opin. Microbiol. 5, 240-245. doi:10.1016/S1369-5274(02)00324-7

Truu, M., Truu, J., Heinsoo, K., 2009. Changes in soil microbial community under willow coppice: The effect of irrigation with secondary-treated municipal wastewater. Ecol. Eng., Molecular and microbial advances in wetland science 35, 1011-1020. doi:10.1016/j.ecoleng.2008.08.010

Vacca, G., Wand, H., Nikolausz, M., Kuschk, P., Kästner, M., 2005. Effect of plants and filter materials on bacteria removal in pilot-scale constructed wetlands. Water Res. 39, 1361-1373. doi:10.1016/j.watres.2005.01.005

Weber, K.P., Legge, R.L., 2011. Dynamics in the bacterial community-level physiological profiles and hydrological characteristics of constructed wetland mesocosms during start-up. Ecol. Eng., Advances in pollutant removal processes and fate in natural and constructed wetlands 37, 666-677. doi:10.1016/j.ecoleng.2010.03.016

Wohl, D.L., Arora, S., Gladstone, J.R., 2004. Functional Redundancy Supports Biodiversity and Ecosystem Function in a Closed and Constant Environment. Ecology 85, 1534-1540. doi:10.1890/03-3050

Wu, S., Kuschk, P., Wiessner, A., Müller, J., Saad, R.A.B., Dong, R., 2013. Sulphur transformations in constructed wetlands for wastewater treatment: A review. Ecol. Eng. 52, 278-289. doi:10.1016/j.ecoleng.2012.11.003 